FIRM Journal of Management Studies, Vol. 6(2), September, 2021

ISSN: 2527-5852 (Print) | ISSN 2541-3473 (Online)

DOI: $10.33021 /$ firm.v6i2.1554

\title{
MEASUREMENT OF FINANCIAL RISK TO ECONOMIC POLICY IN INDONESIA
}

\author{
Yoseva Maria Pujirahayu Sumaji ${ }^{a}$, \\ anternational Business Management Department, Faculty of Management Business, Ciputra University, \\ Indonesia \\ *yoseva.maria@ciputra.ac.id
}

\begin{abstract}
The world of economy is in a state of uncertainty as shown by the improvement in the projected growth of the world by international institutions. The state of development of the world economy is flutuative due to declining economic growth of developed and developing countries, lower commodity prices, and the difference in direction between monetary and fiscal policy. The development of the world economy can be seen from the Real Effective Exchange Rate (REER) indicator, which sees the exchange rate as a measure of the state of the world economy. This can attract investors to invest in Indonesia due to good REER conditions. REER can be used as one of the reference by investors to make investment decisions in the company that will later affect the company's decision-making. Decision-making will determine how far the company will experience the financial risks that will be set up in risk management. The discussion in this paper is to measure risk using the C-FaR method for an equivalent comparison of Go-public non-financial companies on the IDX and to conduct an analysis to see the benefits in determining a future policy related to risk management applications. There are 120 non-financial companies registered with IDX Indonesia. The sampling techniques in this study used nonprobability sampling. The inferential statistical analysis conducted in this study is through classic assumption tests, regression analysis, mediation tests and hypothesis tests. The results of the study showed that the Risk Measurement of Economic Policy in Indonesia had a significant positive effect.
\end{abstract}

Keywords: Risk Measurement, Economic Policy

\section{Introduction}

The economy is being there on the condition that overwhelmed the uncertainty shown by the improvement of the projected growth in economic by institutions internationally. The weak growth of the world economy was caused by the economic growth of developed and developing countries, the difference in direction between monetary and fiscal policies, and the decline in commodity prices.

According to the Ministry of Finance, the development of the world economy can be seen from the indicators Real Effective Exchange Rate (REER), the development of the world economy can be seen from the indicators Real Effective Exchange Rate (REER), which saw the exchange rate as a measure AKAT world economic condition. This can attract investors to invest in Indonesia due to good REER conditions. REER can be used as a reference by investors in making investment decisions in companies which will later affect the company's decision making. Decision making will determine how far the company will experience financial risk which will be regulated in risk management.

Decision making will determine how far the company will experience financial risk which will be regulated in risk management. Maria (2016) states that risk management is defined as a process of identifying, measuring and controlling financial risk that may arise and caused losses on assets. The emergence of risk due to the existence of an uncertainty that uncertainty is a condition that results in the growth of risk caused by doubt someone ability to predict the results of future.

The conditions of the uncertainty of the policy decision-making due to various reasons including the difference between planning and implementation, and execution that generates output. Were, throughout the longer the time, the longer the uncertainty of the policy will be 
given. The limited information needed in the design of a plan is also an indicator that causes uncertainty about a policy which also results in a lack of access to accurate information making it difficult to make or plan a policy which leads to doubts in deciding policies (Maria, 2016).

Knowing with certainty a risk can be said to be able to measure the risk with a good method so as to make the method a reference for taking appropriate action and minimizing the occurrence of an uncertainty in a policy. This is also the right basis for what policies will be carried out. Methods in risk management were first developed by and for the financial industry as well as banks and these methods were developed and adopted by funding companies mainly in Indonesia which is for hedging and industrial companies (Crouhy et al., 2001).

The most well-known method of measuring market risk is the Value at Risk (VaR) method which was originally developed by JP Morgan (1999) and still has a continuing impact on current risk measurement practices in the financial industry. According Jorion (2005), VaR is a method to measure risk by using statistical techniques.

In 2007, survey results showed that more than $60 \%$ of global financial institutions manage their risk exposure by applying this $\mathrm{VaR}$ technique. The developmental advantages of this method can mainly be attributed to the fact that it offers the possibility of combining multiple risk exposures into a single measure, thereby increasing the efficiency and effectiveness of risk monitoring and decision-making activities (Deloitte, 2013). VaR has been widely used by regulators to set capital adequacy requirements for financial services companies. All these perspectives prescribe an incisive and compelling instrumental approach to 'decision making under uncertainty' (Fisher, 2001).

Currently, the implementation of risk management in Indonesia is increasingly being recognized as important and this is also encouraged by the issuance of several regulations related to the application of risk management and hedging applications for the banking industry and state-owned enterprises institutions. At times like this, as explained earlier, it requires the non-financial industry to implement risk management. On the other hand, studies on risk measurement methods in non-financial institutions are still relatively few in Indonesia. According to Culp, (2002) that Var may be useful in financial companies in the context of the determination of derivative prices of the exotic and monitors trading risk on a daily basis, but it does provide limited benefits for non-financial companies to manage risk exposure in the market illiquid ( illiquid market ) and over a longer time horizon. The Ministry of Industry noted that manufacturing sector investment in January-September 2020 grew 37.1 percent compared to the same period last year (Kemenperin, 2021).

Based on the explanation above, the application of risk management measurement in determining policies in the non-financial industry in Indonesia is interesting to be discussed further and in depth. The discussion in this paper is to measure risk using the C-FaR method for an equivalent comparison of Go-public non-financial companies on the IDX and to conduct an analysis to see the benefits in determining a future policy related to risk management applications. The development of the world economy can be seen from the Real Effective Exchange Rate (REER) indicator, which sees the exchange rate as a measure of the state of the world economy. This can attract investors to invest in Indonesia due to good REER conditions. REER can be used as one of the reference by investors to make investment decisions in the company that will later affect the company's decision-making. Decision-making will determine 
how far the company will experience the financial risks that will be set up in risk management. The discussion in this paper is to measure risk using the $\mathrm{C}-\mathrm{FaR}$ method for an equivalent comparison of Go-public non-financial companies on the IDX and to conduct an analysis to see the benefits in determining a future policy related to risk management applications.

\section{Literature Review}

\section{Risk Management}

Risk management is a set of procedures and methodologies used to identify, measure, control, and control risks arising from a bank's business activities. This is related to the general definition of risk, that is, in every business / activity there is always the possibility of not achieving a goal or there is always uncertainty over any decision that has been taken. A condition arising from uncertainty with all the unfavorable consequences that may occur is called "risk". Unfavorable consequences refer to the realization of business objectives, namely the right cost, on time, and the right quality of results so that risks are related to future events and involve choices and uncertainty that the choice will be made.

There are many notions of risk, but it leads to the same explanatory outcome or output. Here are some notions of risk according to some experts: According to Abbas (1998), risk is an uncertainty or uncertainly that can cause damage or loss. Ferdinan Silalahi (1997) suggests that risk is a deviation of actual results from expected or results that are different from expected. Meanwhile, Kasidi (2010) suggested that risk is a possibility of deviations from expectations that can cause losses. Risk can be attributed to the possibility of an unintended, or unexpected loss which means that "possibility" already indicates that uncertainty is causing the growth of risk.

Risk management is a system of risk supervision and protection of property, property rights and profits of business entities or individuals or the possibility of loss due to a risk. According to Irham Fahmi (2010: 2) Risk Management is "a field of science that discusses how an organization applies size in mapping existing problems by placing various management approaches comprehensively and systematically." Risk management is defined as a logical and sitematic method of identifying, quantifying, determining attitudes, establishing solutions, and monitoring and reporting the risks that take place in each activity or process. According to the large dictionary Indonesian quoted from (Tony Peramanna 2011), risk is "a less pleasant (adverse, harmful) consequence of an act or action." In other words, risk is a possible situation or circumstance that could threaten the achievement of the organizations.

\section{Benefits of Risk Management}

According to Irham Fahmi (2010: 3) with the implementation of risk management in one company, there are several benefits that will be obtained, namely: a) The Company has a strong measure as a foothold in taking every decision, so that managers become more prudent and always put measures in various decisions. b) Able to give direction for a company in seeing the influence of influence that may arise both in the short and long term. c) Encourage managers in making decisions to always avoid the influence of losses, especially in terms of finances. d) Allow the company to obtain a minimum risk of loss. e) With the concept of risk management designed in detail, it means that the company has built direction and mechanisms in a sustainable manner. 


\section{Decision-making policy}

Davis in Hasan (2002) describes those decisions are the solution of problems faced firmly. According to Davis, the decision must be able to answer the question of what is discussed in relation to a plan, and can also be an action on implementation that deviates greatly from the original plan. Associated with the purpose of financial statements, it provides useful information for most of the report users or stakeholders to make economic decisions. In this case, decision making plays an important role in accounting theory, especially from management who always consider whether a financial statement will be presented in a timely manner or postponed.

In a financial statement there is good news, which will encourage management to deliver the company's financial statements in a timely manner due to high incentives and profitability of the company. Punctuality is also influenced by investor reactions that have implications for rising stock prices. Similarly, financial statements are said to be bad news when the profitability of the company decreases or losses, it will be a bad reaction for investors who have implications for the decline in the stock price which consequently will also tone the withdrawal of investments by investors or do not want to invest again. Here is the financial Model that applied in Indonesia:

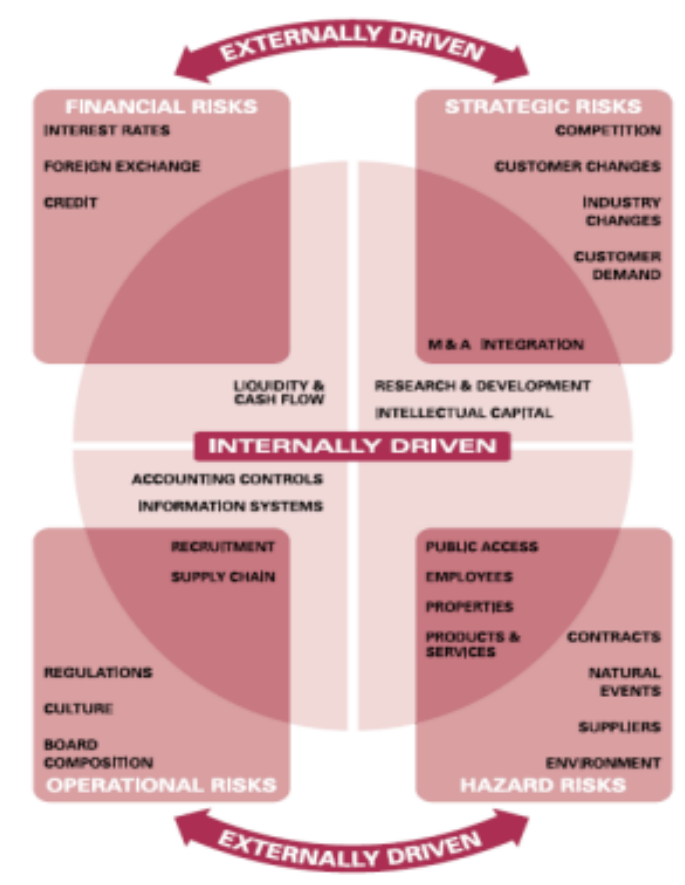

Figure 1. Financial Decision Making in Indonesia

Source: Risk Management Standard, The Institute of Risk Management: AIRMIC, ALARM (IRM, 2002)

Submission of financial statement information for decision making must have useful value for all users of financial statements. As revealed by Hasan (2002), decision making is heavily influenced by the availability of necessary information, where the information must be complete and meet certain properties so that the results are quality. The nature that must be fulfilled includes accurate, meaning that the information must be in accordance with the actual 
circumstances, comprehensive, that is, the nature must be able to represent and relevant, which means by dealing with a problem that is as soon and must be resolved.

Regarding the submission of financial statements from external parties, opinions issued by auditors become a reference or handle for stakeholders as well as to investors to know the level of feasibility of the information presented by the company. If there are things that encourage the auditor to add audit details, then the audit process will take longer.

\section{Method}

According to Sugiyono (2010), the sample is part of a number of characteristics shared by the population. The sample is representative of the population partly or studied. The sampling technique in quantitative research is non- probability sampling (non-random sampling). Nonprobability sampling is a sampling technique does not provide opportunities or opportunities equal for each element or members selected into the sample (Sugiyono, 2010). As part of nonprobability sampling, purposive sampling was used. Purposive sampling is a sampling technique by means certain considerations (Sugiyono, 2010). Sampling is done by taking samples from the population based on certain criteria. In this study, the criteria used are with certain considerations, namely: Indonesian companies listed on the Indonesian stock exchange and IPOs in the research year. From the above criteria, this resulted in a final sample consisting of 120 companies selected for analysis. Based on the sample selected in the five years' period used to determine the data, so the unit of analysis is 120 samples $x 4$ years.

Explanative research will collect data through secondary sources. In this study, secondary data were collected from the Indonesia Stock Exchange (IDX) database. The researcher uses financial information data from financial statements and annual reports of Indonesian non-financial and financial companies listed on the Indonesia Stock Exchange (IDX) during the sample period 2015-2019. The purposive sampling technique was chosen to collect and the researcher has a final sample of 120 companies in 2015-2019.

To find out the analysis, testing must be done is to use the following tools:

1. Test Normality: testing aims to examine the residual confounding variables have a normal distribution or not. One of the easiest ways to see residual normality is to look at a histogram graph that compares the distribution of data with observations that are close to a normal distribution. A more reliable method is to look at a normal probability plot comparing the cumulative distribution with the normal distribution. The normal distribution will form a straight diagonal line, and plotting the residual data will be compared with the diagonal line. If the residual normal distribution of the data, then the line that describes the actual data will follow the diagonal line Ghozali (2006).

2. Multicollinearity: This test aims to find a correlation between the independent variables (independent). The regression model should not have a good correlation between variables. If the independent variables are correlated with each other, then this variable is not orthogonal. Ghozali (2006). In a technical study to detect whether there is multicollinearity in the regression model, it can be seen from the tolerance value and the Variance inflation factor (VIF), the tolerance value which is above 0.1 and 10 below the VIF 
value indicates that there are independent variables among the multicollinearity Ghozali (2006).

3. Heterocedasticity Test: This test is carried out to analyze whether there is an inequality of variance in the residual observations of other observations or not. We can see it from the graph plot between the predictive variable (ZPRED) and residual (SRESID). The basic analysis used is: If there is a certain pattern, such as dots that have a certain pattern or irregular shape, it indicates that Heterocedasticity has occurred. On the other hand, when the points are spread below and above 0 on the y-axis, there is no heteroscedasticity (Ghozali, 2006).

4. Autocorrelation: It is used to find out the relationship between the occurrences of a sample of members sorted by time. The consequence of autocorrelation in the regression model is that the sample variance cannot describe the population.

\section{Results and Discussions}

\section{Classic Asumption Test}

Ghozali (2005) mentioned that the normality test using the Kolmogrov-Smirnov Goodness of Fit Test is a reliable test to test the normality of a model.

Table 1. Normality Test Results using One-Sample Kolmogorov-Smirnov Test

\begin{tabular}{|c|c|c|}
\hline \multicolumn{3}{|c|}{ One-Sample Kolmogorov-Smirnov Test } \\
\hline $\mathbf{N}$ & & 480 \\
\hline \multirow[t]{2}{*}{ Normal Parameters ${ }^{\mathrm{a}}$} & Mean & 30.6707143 \\
\hline & $\begin{array}{l}\text { Std. } \\
\text { Deviation }\end{array}$ & 26.79443936 \\
\hline \multirow[t]{3}{*}{ Most Extreme Differences } & Absolute & .104 \\
\hline & Positive & .104 \\
\hline & Negative & -.086 \\
\hline Kolmogorov-Smirnov Z & .672 & \\
\hline Asymp. Sig. (2-tailed) & .756 & \\
\hline
\end{tabular}

Table 1 shows that the significance value of 0.756 is greater than 0.05 . This indicates that the models and data used are normal distribution.

\section{Multicollinearity tests}

Multicollinearity tests aim to test whether in regression models there is a correlation between independent variables. A good regression model should not be a correlation between free variables. To see the existence of multicollinearity or not, it can be seen from the value of tolerance and variance factor (VIF). Here are the results of the multicollinearity test from the data that has been processed:

\begin{tabular}{llcc}
\multicolumn{4}{c}{ Table 2. Multicollinearity Test Results } \\
\hline \multicolumn{3}{c}{ Model } & \multicolumn{2}{c}{ Collinearity Statistics } \\
Tolerance & VIF \\
\hline $\mathbf{1}$ & ROA & .975 & 1.026 \\
& Firm_Size & .738 & 1.354 \\
& Debt_Ratio & .801 & 1,249 \\
& Current_Ratio & .591 & 1,693 \\
\hline
\end{tabular}

Resource: data processed, 2021. 
In table 2 it can be seen that the value of tolerance and variance inflation factor (VIF), tolerance values that are above 0.1 and VIF values below 10 . This indicates that there is no multicollinearity between its free variables.

\section{Heteroscedasticity Test}

This test is conducted to analyze whether in regression models there is variance inequality from residual observation to other observation. A good regression model is one that does not occur heteroscedasticity. According to Ghozali (2006) The heteroscedasticity test aims to test whether in regression models there is a residual variance inequality from residual one observation to another observation. If the variance from residual one observation to another observation remains, it is called homoscedasticity and if heteroscedasticity differs. A good regression model is homoskedasticity or no heteroscedasticity. How to detect the occur or absence of heteroskedasticity by doing the Glejser test method. The Glejser test is performed by regreging the residual absolute value of the model estimated against explanatory variables. To detect the absence of heteroskedasticity is seen from the probability value of each independent variable. If the probability of $>0.05$ means that there is no heteroscedasticity, conversely if the probability of $<0.05$ means heteroscedasticity occurs. In addition, there is a white test method to see there is no heteroskedasticity in the model. Heteroskedasticity can be seen using the following results:

Table 3. Heteroscedasticity Test

\begin{tabular}{|c|c|c|c|c|c|c|}
\hline \multicolumn{2}{|c|}{ Model } & \multicolumn{2}{|c|}{$\begin{array}{l}\text { Unstandardized } \\
\text { Coefficients }\end{array}$} & \multirow{2}{*}{$\begin{array}{c}\begin{array}{c}\text { Standardized } \\
\text { Coefficients }\end{array} \\
\text { Beta }\end{array}$} & \multirow[t]{2}{*}{$\mathbf{t}$} & \multirow[t]{2}{*}{ Sig. } \\
\hline & & $\mathrm{B}$ & Std. Error & & & \\
\hline \multirow[t]{6}{*}{1} & (Constant) & 8.081 & 3.123 & & 4.234 & .005 \\
\hline & Measurement_Risk & .717 & .219 & .089 & 1. & .064 \\
\hline & ROA & .401 & .086 & .121 & 1.982 & .101 \\
\hline & Firm_Size & -1.082 & .791 & -.173 & $\begin{array}{r}- \\
1.451\end{array}$ & .010 \\
\hline & Debt_Ratio & .921 & .173 & .514 & 7.128 & .000 \\
\hline & Current_Ratio & -.081 & .089 & -.074 & -.498 & .345 \\
\hline
\end{tabular}

Resource: data processed, 2021.

Data processed by downloading NOTICE simple linear regression done through several stages that aims to determine the effect of the independent variable on the dependent variable with the variable control. Multiple regression analysis was as follows

Table 4. Regresion Test Result

\begin{tabular}{|c|c|c|c|c|c|c|c|c|}
\hline \multicolumn{9}{|c|}{ Coefficients $^{\text {a }}$} \\
\hline \multirow{2}{*}{\multicolumn{2}{|c|}{ Model }} & \multicolumn{2}{|c|}{$\begin{array}{l}\text { Unstandardized } \\
\text { Coefficients }\end{array}$} & \multirow{2}{*}{$\begin{array}{c}\text { Standardized } \\
\text { Coefficients } \\
\text { Beta } \\
\end{array}$} & \multirow[t]{2}{*}{$\mathrm{t}$} & \multirow[t]{2}{*}{ Sig. } & \multicolumn{2}{|c|}{$\begin{array}{c}\text { Collinearity } \\
\text { Statistics }\end{array}$} \\
\hline & & B & Std. Error & & & & Tolerance & VIF \\
\hline \multirow[t]{6}{*}{1} & (Constant) & 6.062 & 2.013 & & 3.011 & .003 & & \\
\hline & Measurement_Risk & .356 & .191 & .098 & 1.994 & .063 & .975 & 1.026 \\
\hline & ROA & .120 & .073 & .100 & 1.652 & .100 & .738 & 1.354 \\
\hline & Firm_Size & -2.027 & .767 & -.153 & 2.641 & .009 & .801 & 1.249 \\
\hline & Debt_Ratio & .981 & .160 & .414 & 6.128 & .000 & .591 & 1.693 \\
\hline & $\begin{array}{l}\text { Current_Ratio } \\
\text { pendent Variable: I }\end{array}$ & -.092 & .095 & -.065 & -.964 & .336 & .595 & 1.679 \\
\hline
\end{tabular}

Processed data, 2021

Based on Table 4, there are results from simple linear regression of risk-taking policy:

Policy $=6.6062+0.356$ Risk Measurement +0.120 ROA -2.027 Firm Size +0.981 Debt

Ratio - 0.092 Current Ratio. From the multiple regression model above, it can be interpreted as follows:

1. The constant of 6.6062 indicates that if there are no independent variables or in other words all independent variables are zero, then the Decision Making Policy is 6.6062. 
2. Pe ngukuran Risk has a value of 0.356 . This shows that every change in Risk Measurement is 1 unit with the assumption that other variables are considered constant, then the Decision Making Policy will increase by 0.356 .

3. ROA has a value of 0.120 . This shows that every change in ROA is 1 unit with the assumption that other variables are considered constant, then the Decision Making Policy will increase by 0.120 .

4. Firm Size has a value of $-2,027$. This shows that every Firm Size change is 1 unit with the assumption that other variables are considered constant, then the Decision Making Policy will decrease by 2.027 .

5. Debt Ratio has a value of 0.981 . This shows that every change in the Debt Ratio is 1 unit with the assumption that other variables are considered constant, then the Decision Making Policy will increase by 0.981 .

6. Current Ratio has a value of -0.092 . This shows that every change in the Current Ratio is 1 unit with the assumption that other variables are considered constant, then the DecisionMaking Policy will experience a Current Ratio of 0.092 .

Simultaneously test the hypothesis, the $F$ test $(F$ test) is used, where the calculated $F$ value is compared with the $F$ table value at a certain level of confidence. This simultaneous significance test is used to test all independent variables. The following are the results of the Simultaneous Significance test:

Table 5. Simultaneous Significance Test Results

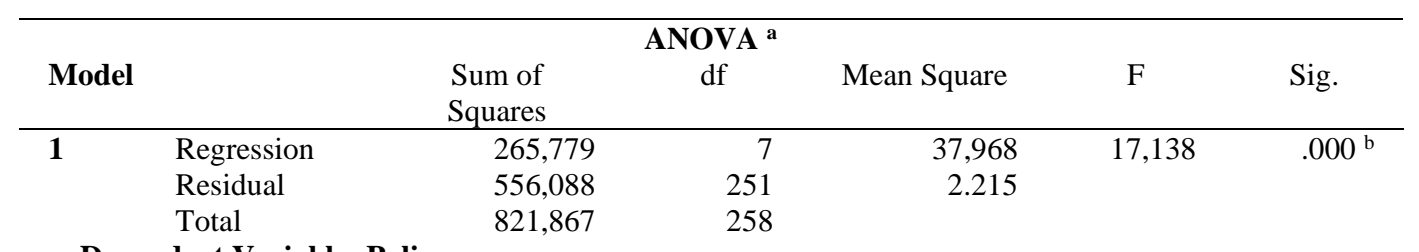

a. Dependent Variable: Policy

b. Predictors: (Constant), Current_Ratio, Measurement_Risk, Firm_Size, ROA, Debt_Ratio

Source: processed data, 2021

From the table above it can be seen that the value of $\mathrm{F}_{\text {arithmetic }}$ amounted

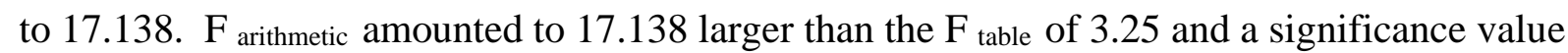
of 0.000 smaller than the value of $\alpha(0.05)$. This shows that all independent variables have a simultaneous effect on the dependent variable, therefore $\mathrm{HO}$ is rejected, and $\mathrm{Ha}$ is accepted which is controlled by the ROA, Firm Size, Debt Ratio and Current Ratio variables for the control variables of Decision Making Policy.

The $t$ test is intended to partially test the regression relationship of the independent variables to the $t_{\text {test }}$ to test the level of significance of the relationship between each regression coefficient. The $t$ test is used to partially test the relationship between the independent and dependent variables. This hypothesis test uses the $t$-test $(t$ test $)$, where $t$ count is compared with $t$ table at a certain level of confidence. The test results are as follows:

Table 6. Partial Significance Test Results

\begin{tabular}{|c|c|c|c|}
\hline Variable & t count & $t_{\text {table }}$ & Information \\
\hline Measurement_Risk & 1.994 & 1979 & Significant \\
\hline ROA & 1,652 & 1979 & Not significant \\
\hline Firm_Size & $-2,641$ & 1979 & Significant \\
\hline Debt_Ratio & 6.128 & 1979 & Significant \\
\hline Current_Ratio & -.964 & 1979 & Not significant \\
\hline
\end{tabular}

Source: processed data, 2021

Testing on the Risk Measurement variable shows that $t_{\text {count }}>t_{\text {table }}$ is $(1.994)>$ 1.979. This shows that Ha is accepted which means that Risk Measurement has a partial effect on Decision Making Policy. Testing on the ROA variable shows that $t_{\text {count }}>t$ table is $(1,652)$ 
$<1,979$. This shows that Ha is rejected, which means that the Risk Measurement does not partially affect the Decision-Making Policy. Testing on the Firm Size variable shows that $\mathrm{t}_{\text {count }}>\mathrm{t}_{\text {table }}$ is $(-2,641)>1,979$. This shows that $\mathrm{Ha}$ is accepted which means that Firm Size has a partial effect on Decision Making Policy. Testing on the Debt Ratio variable shows that $t_{\text {count }}>t$ table is $(6,128)>1,979$. This shows that Ha is accepted which means that the Debt Ratio has a partial effect on Decision Making Policy. The test of the current ratio variable shows that $\mathrm{t}_{\text {count }}>\mathrm{t}_{\text {table }}$ is $(-0.964)>1.979$. This shows that $\mathrm{Ha}$ is accepted which means that the Current Ratio has a partial effect on Decision Making Policy.

According to Soesino (1999), to analyze risk, it is necessary to know beforehand about the position of risk, including hazard (a condition that can increase the possibility of a peril), peril (a condition that can cause a loss, such as: loss of debt, bankruptcy, and loss of a market share) and losses (are losses suffered as a result of an unexpected event but it happened) .

This indicates the impact of uncertainty on a policy from unexpected risks. Uncertainty will also hamper economic growth and this will lead to a decrease in the level of surplus. Risk management is one of the important elements in a company even in a country. This is related in an effort to minimize the occurrence of a risk that occurs in carrying out the flow of the economy which is as stated by Djojosoedarso (2003) which states that risk management is the application of the management function in overcoming the risks faced by companies, families and communities. The activities planned, organize, lead or coordinate, and supervise and evaluate programs to overcome risk.

Knowing with certainty a risk can be said to be able to measure the risk with a good method so as to make the method a reference for taking appropriate action and minimizing the occurrence of an uncertainty in a policy. This is also the right basis for what policies will be carried out. Methods in risk management were first developed by and for the financial industry as well as banks and these methods were developed and adopted by funding companies mainly in Indonesia which is for hedging and industrial companies (Crouhy et al., 2001).

The most well-known method of measuring market risk is the Value at Risk (VaR) method which was originally developed by JP Morgan (1999) and still has a continuing impact on current risk measurement practices in the financial industry. According Jorion (2005), VaR is a method to measure risk by using statistical techniques.

Currently, the implementation of risk management in Indonesia is increasingly being recognized as important and this is also encouraged by the issuance of several regulations related to the application of risk management and hedging applications for the banking industry and state-owned enterprises institutions. At times like this, as explained earlier, it requires the non-financial industry to implement risk management. On the other hand, studies on risk measurement methods in non-financial institutions are still relatively few in Indonesia. The success of the VaR methodology in the financial sector has stimulated interest in the nonfinancial industry to develop this method in an "at risk" technique adapted for the environment.

In the results of the study, it is known that the measurement of risk, firm size and debt ratio can be used as a basis for determining company policies. This is because Firm Size is the size of the company that determines the size of the company that can be the basis for determining company decision making, the larger the size of the company, the company must be more careful in making decisions because if the wrong decision is made it will affect the capital structure and assets. company, the decisions taken by the company are also determined by the company's many stakeholders. The debt ratio is also a determinant of the company's 
decision making because of the importance of the company knowing the company's debt ratio so that the decisions made do not increase the company's debt and can even reduce the company's debt.

In the results of the study, it is known that ROA and Current Ratio have no direct effect on company decision making because company decision making in non-financial companies does not refer to assets or assets owned by a company, but rather to company size and company debt ratio. Based on the explanation above, the application of risk management with measurements in policy determination in the non-financial industry in Indonesia has significant results between risk measurement, firm size and debt ratio on corporate decision making, while ROA and current ratio have no effect on company decision making.

\section{Conclusions and Recommendations}

The results of the study indicate that the development of financial risk management and uncertainty on economic policies in Indonesia in its measurement using the influence of risk management measurements on economic decision-making policies has a significant positive effect. Research should be carried out over a longer period of time (above 5 years) and cover all industries in Indonesia in order to see a longer effect. The development of financial risk management and the uncertainty of economic policy in Indonesia can be used for risk management as a standard measurement of decision making so that non-financial companies in Indonesia can be careful in taking economic policies in accordance with their risk management measurements.

\section{Acknowledgements}

We acknowledge the support received from Ciputra University and LPPM Ciputra University who has provided funding for this research

\section{References}

Abbas Salim. (1998). Asuransi dan Manajemen Resiko. Jakarta: PT. Raja Grafindo Persada. Crouhy, Michel, et. al. Risk Management. McGraw-Hill, 2001.

Culp, Christopher, L. (2002) The Art of Risk Management (Alternative Risk Transfer, Capital, Structure and the Convergence of Insurance and Capital Market). New York: John Willey \& Sons.

Deloitte. (2013). Global risk management survey, eight edition: Setting a higher bar. Acces on January, $\quad 11$ st, 2015 from www.deloitte.com/assets/dcomunitedstates/local\%20assetsdocument/us_fsi_aers_glob al_risk_management_survey_8thed_072913.pdf.

Djojosoedarso, S. 2003. Prinsip-Prinsip Manajemen Resiko dan Asuransi, Edisi. Revisi. Jakarta: Salemba Empat.

Fahmi, Irham. 2010. Manajemen Resiko. Bandung: Alfabeta

Fisher,S, (2001). Risk Management in Top Priority in Bank Restructuring. Jakarta: The Boston Consulting Group.

Ghozali, Imam, (2005). Aplikasi Analisis Multivariate dengan Program SPSS.

Semarang: Badan Penerbit Universitas Diponegoro

-. (2006). Aplikasi Analisis Multivariate dengan Program SPSS (Edisi Ke 4). Semarang:Badan Penerbit Universitas Diponegoro. 
Hasan, M.Iqbal. (2002). Pokok-pokok materi pengambilan keputusan. Jakarta :Penerbit Ghalia Indonesia.

Indriantoro, Bambang, (2002). Metode Penelitian Bisnis: Untuk Akuntansi \& Manajemen. Edisi pertama. Cetakan kedua. Yogyakarta: BPFE

Institute of Risk Management (IRM). 2002. A Risk Management Standard. AIRMIC, ALARM: United Kingdom.

Jorion, Philippe. (2005). Financial Risk Manager Handbook. 3rd Edition, John Wiley \& Sons, Inc.

JP Morgan. (1999). Risk Management: Technical Document. Risk Metrics Group, New York.

Kasidi. (2010). Manajemen Risiko. Bogor: Ghalia Indonesia

Kemenperin, (2021). Kemenperin Bidik Sektor Industri Tumbuh 3,95\% Tahun 2021. Access on March 23rd, 2021 form https://kemenperin.go.id/artikel/22159/KemenperinBidik-Sektor-Industri-Tumbuh-3,95-Tahun-2021.

Maria, Yoseva, (2016). Analysis of Market Risk in Stock Investment Using Value at Risk Method (Study on Manufacturing Companies in Lq-45 Listed on Indonesia Stock Exchange. Journal Asia-Pacific Management and Business Application, Vol 6 (1) : 114

Pramana, Tony. (2011). Manajemen Risiko Bisnis. Jakarta : Sinar Ilmu

Silalahi, Ferdinand (1997). Manajemen Risiko dan Asuransi. Jakarta: Gramedia PustakaUtama. Sugiono, (2007). Metode Penelitian Kuantitatif Kualitatif dan R\&D. Bandung: Alfabeta

Soesilo, Nining I. 1999. Ekonomi, Perencanaan dan Manajemen Kota,Magister Perencanaan dan Kebijakan Publik. Universitas Indonesia: Jakarta 